\title{
Measurements of the Fallout Flux of Beryllium-7 and its Variability in the Soil
}

\author{
Avacir Casanova Andrello* and Carlos Roberto Appoloni \\ Departamento de Física; Universidade Estadual de Londrina; 86051990; C. P.. 6001; Londrina - PR - Brasil
}

\begin{abstract}
The aim of this study was to examine the beryllium-7 behavior in the soil. Natural variability of beryllium-7 concentration was calculated to be about $23 \%$ (relative standard deviation), and the depth distribution could be approximated by an exponential decay in bare soil, with an average penetration depth in the soil about $1 \mathrm{~cm}$. The nuclide was not found below $2 \mathrm{~cm}$ depth, which confirmed its utilization to infer the erosion processes as a tracer of soil surface. The maximum beryllium-7 concentration in the analyzed period was about $40 \mathrm{~Bq} \cdot \mathrm{kg}^{-1}$.
\end{abstract}

Key words: beryllium-7, gamma ray spectrometry, superficial soil erosion

\section{INTRODUCTION}

The on-site and off-site impacts of soil erosion and its role in the mobilization and transport of sediment-associated nutrients and contaminants has highlighted the need to determine the soil erosion rates. Traditional methods used to document the soil erosion rates possess many limitations. Erosion plots have been widely used in soil erosion research, but provide only a measure of the net soil loss from the total area covered by the plot, and the values of net soil loss obtained may be unrepresentative of larger landscape units where slope lengths are longer and greater opportunities for deposition events may occur (Loughran, 1989; Toy et al, 2002).

The developments in the use of the artificial radionuclide cesium-137 to soil erosion assessment represent an important advance that overcomes many limitations of the exising techniques to document the rates and patterns of soil redistribution in the landscape. The key advantages of the cesium-137 approach are the potential to obtain retrospective data and the provision of spatially distributed information on the erosion and deposition rates, on the basis of a single site visit, establishing sediment delivered ratios, the medium term average rates of soil redistribution, besides of its applicability to different environments. However, the cesium-137 methodology has some limitations that are the time-integrated nature of soil redistribution rates, which provide an average value for last 45 years and reflect the whole effects of both water and wind erosion and soil redistribution by tillage activity (Govers et al, 1996; Andrello et al, 2003, 2004a). It is necessary to separate the erosion and tillage components if information on water and wind erosion alone is required. A radionuclide with a similar behavior to cesium-137, but has continuous input and a half-life with order of days rather than years, the beryllium-7, has been used to document short-term contemporary erosion rates. Use of the complementary radionuclides,

*Author for correspondence: acandrello@uel.br 
beryllium-7 and cesium-137, could greatly extend the scope of information on short- and mediumterm erosion rates (Walling et al, 1999).

Beryllium-7 is a cosmogenic radionuclide produced in the upper atmosphere by cosmic ray spallation of nitrogen and oxygen. The nuclear reaction produces $\mathrm{BeO}$ or $\mathrm{Be}(\mathrm{OH})_{2}$ which diffuse through the atmosphere until they attach to an atmospheric aerosol. Subsequent deposition on the land surface, therefore, occurs as both wet and dry fallout. In most environments, beryllium-7 fallout reaching the soil surface will be rapidly and strongly fixed by the soil surface. The half-life of beryllium-7 is 53 days and decay by electron capture transitions, whose detectable decay radiation is a gamma ray of $477.56 \mathrm{keV}$.

Beryllium-7 has been applied in many fields, such as sediment sources assessment, concentration in air, air mass transport, study of metal scavenging processes and others applications (Yoshimori, 2005; Steinmann et al, 1999; Daish et al, 2005; Matissoff et al, 2002). Some works have demonstrated the potential for using beryllium-7 in tracing of sediment in marine and lacustrine systems and how beryllium-7 could be used to fingerprint sediment derived from superficial sources (Wan et al, 1987; Wallbrink and Murray, 1996; Blake et al, 1999). In South America, only one work carried out in Chile has applied beryllium-7 to study the soil redistribution (Schuller et al, 2006). Schuller et al (2006) employed beryllium-7 to estimate the soil redistribution associated with a period of heavy rainfall within a harvested forest area and showed the applicability of beryllium-7. The aim of this work was to assess the fallout flux of beryllium-7 in the soil and its deposition variability in the region of Londrina city, Parana State, Brazil, to apply in soil erosion rates determination in the future.

\section{MATERIAL AND METHODS}

An area around of the Londrina city was studied. In this area, one site with $4 \mathrm{~m}^{2}$ was detached, isolated and preserved without covering to determine the monthly flux deposition of beryllium-7. The soil type in the area is Red Latosoil, with $80 \%$ of clay, $13 \%$ of silt and $7 \%$ of sand, relief changing from 0 to $0.5 \%$ and a humid subtropical climate with rain in all seasons and medium pluviosity of 1100 mm.ano ${ }^{-1}$.

This site was monthly sampled to assess the beryllium-7 deposition. It was assumed that all beryllium-7 deposition was due to pluviometric precipitation. The sampling was accomplished using a scraper-plate to sample in increments of 0$1 \mathrm{~cm}, 1-2 \mathrm{~cm}$ and $2-3 \mathrm{~cm}$. The results of the samples collected and analyzed in the first month presented concentration of beryllium-7 up to $2 \mathrm{~cm}$, with null concentration below this depth. After these results, the samples of the subsequent months were collected at the same point, where the beryllium-7 concentration was only due to that deposited in the posterior period of the last sampling. The first sampling was realized in September 2004, after a dryness period of three months. Another site close to the first, cultivated with soybean was sampled after the harvest in a grid of $3 \times 3$ point with separation of $9 \mathrm{~m}$ between the points. These samples were used to evaluate the spatial variability of beryllium-7 deposition. This sampling was accomplished using the same scraper plate, with only one increment $(0-3 \mathrm{~cm})$ at each point.

After the samples collection, the samples were dried in air for $48 \mathrm{~h}$, passed in sieve of $2 \mathrm{~mm}$ mesh and put in Marinelli beaker for analysis. The analysis was carried out by the gamma ray spectrometry with HPGe detector and standard shielding for environmental samples analysis. The energy calibration of the system was done using a source of europium-152 and the efficiency was obtained using an IAEA certified soil sample with energy range from 0 to $2 \mathrm{MeV}$. In this work two HPGe detectors, one detector of $66 \%$ relative efficiency and other with $10 \%$ relative efficiency were utilized. The counting time for the sample analysis was 86400 seconds for $66 \%$ and 172800 seconds for $10 \%$. The same system geometry was used with the detectors and the same procedure was utilized for energy calibration and efficiency determination. The efficiency curve for the used HPGe detectors is presented in the Figure 1.

The beryllium-7 concentration for the samples was calculated using equation (1):

$$
\mathrm{A}=\frac{\mathrm{N}}{\varepsilon \cdot \mathrm{p}_{\gamma} \cdot \mathrm{m} \cdot \mathrm{t}}
$$


where $\mathrm{N}$ was the net count under the peak of $477.56 \mathrm{keV}$ gamma line energy that characterized beryllium-7 (in counts), $\varepsilon$ was the efficiency of the detection system for the $477.56 \mathrm{keV}$ gamma line energy (in counts. $\mathrm{Bq}^{-1} \cdot \mathrm{s}^{-1}$ ) obtained from Figure 1, $\mathrm{p}_{\gamma}$ was the absolute probability transition for $477.56 \mathrm{keV}$ gamma line for beryllium-7 (dimensionless), $\mathrm{m}$ was the mass of the analyzed sample (in $\mathrm{kg}$ ) and $\mathrm{t}$ is the counting time (in second).

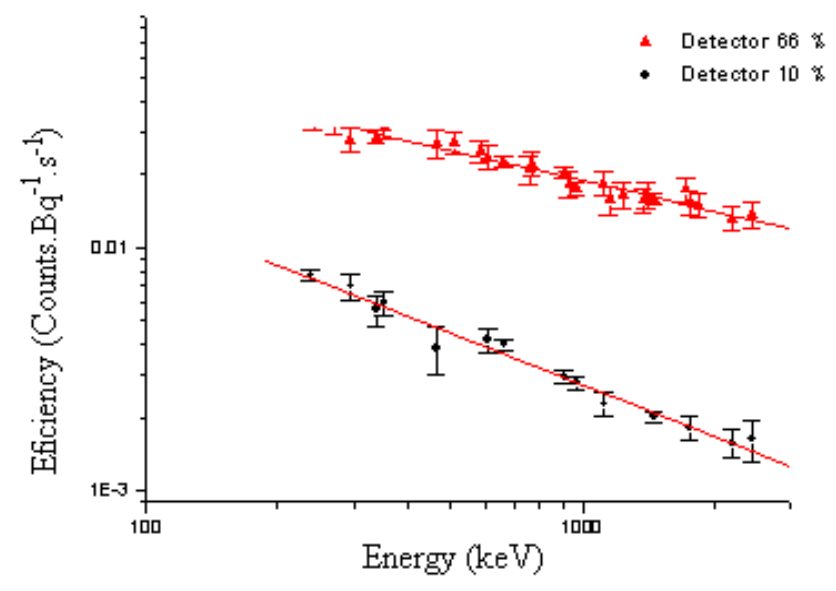

Figure 1 - Efficiency curve obtained with IAEA certified soil sample to HPGe detectors.

\section{RESULTS AND DISCUSSION}

Figure 2 presented the characteristic soil depth profile of beryllium-7 for the analyzed soil type of the studied areas, which showed exponential decay in soil depth, as presented in the literature (Matissoff et al, 2002; Schuller et al, 2006).

Figure 2 showed that the beryllium- 7 deposited in the soil was whole adsorbed in the first $2 \mathrm{~cm}$ of soil, independent of the pluviometric precipitation. The collected samples, observed by direct measure, showed that the soil samples of $2-3 \mathrm{~cm}$ increment didn't present beryllium-7 concentration or this was bellow the detection limit of the system.

The beryllium-7 deposition flux for the evaluated period (September 2004 to February 2006) is presented in Figure 3.

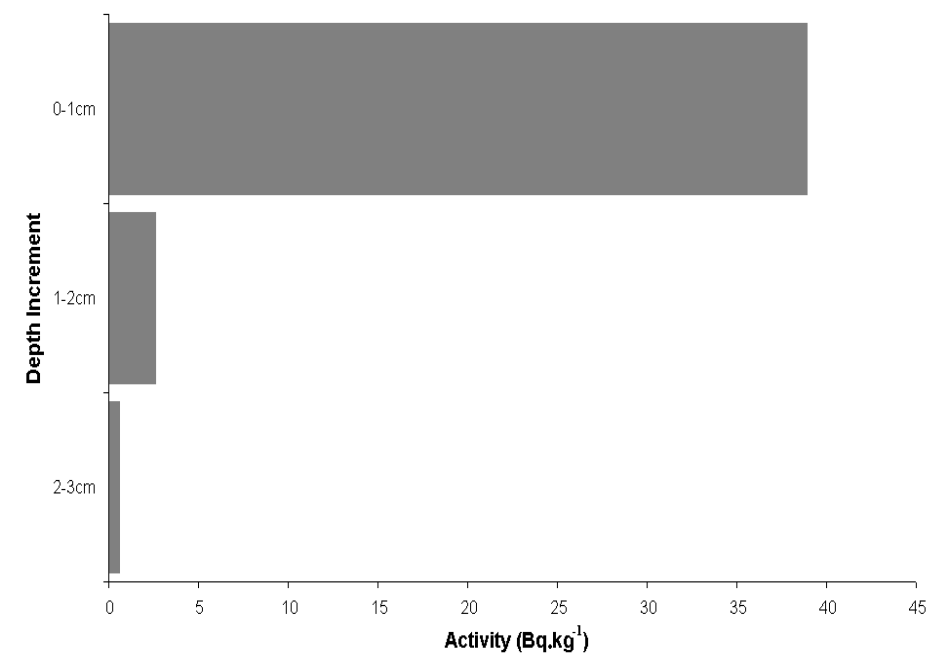

Figure 2 - Characteristic soil depth profile of beryllium-7 in the analyzed soil type. 


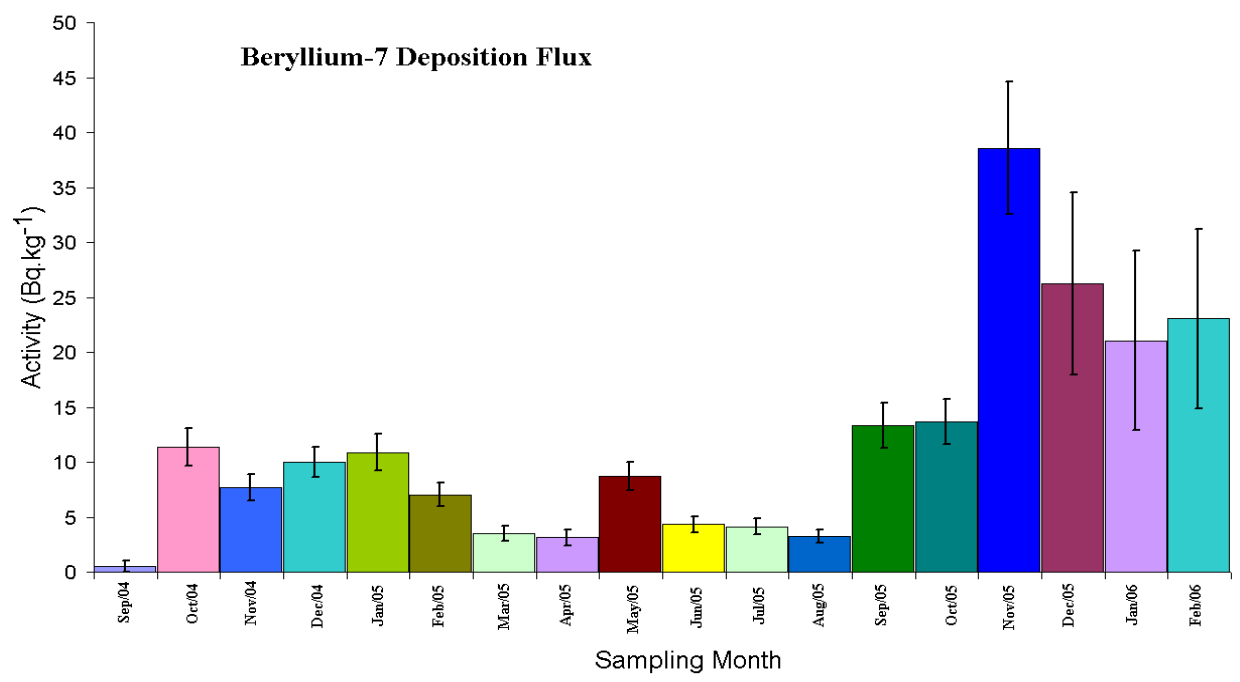

Figure 3 - The beryllium-7 deposition flux from September, 2004 to February, 2005.

Figure 4 presents the pluviometric precipitation for Londrina region, following the data from meteorological station of IAPAR (Instituto Agrônomico do Paraná), which is $2 \mathrm{~km}$ close to the sampled areas (www.iapar.br). The soil sample of September 2004 didn't present beryllium-7 concentration. This could be due to a long dry period in the region, showing that dry precipitation of beryllium-7 was low. However, it should be observed if there was any beryllium-7 in the soil due to pluvial precipitation before the dry period, but as shown in Figure 3, the beryllium-7 concentration was lower in the winter. Moreover, the beryllium-7 deposited in the early of 2004 could have decayed below to the minimum detection limit of the system, which was $2 \mathrm{~Bq} \cdot \mathrm{kg}^{-1}$ to the gamma line of beryllium- 7 .

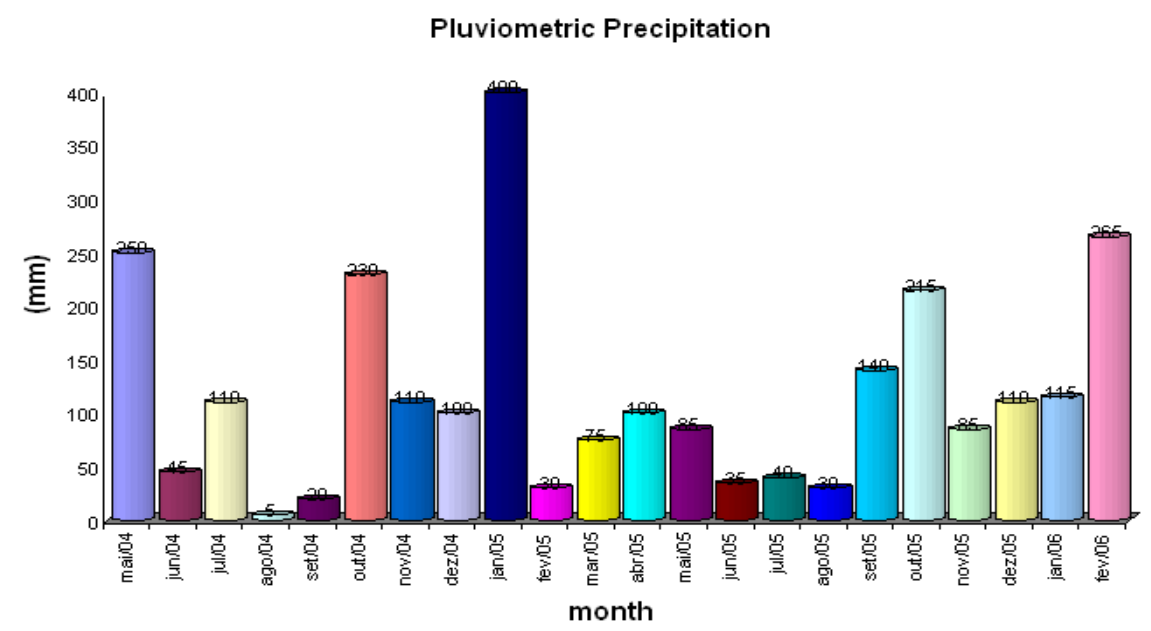

Figure 4 - Pluviometric precipitation occurred on period of May, 2004 to February, 2006. 
Figure 3 showed that the beryllium-7 deposition for the observed period increased until January 2005 and then decreased in the following months. This effect was coherent with the increase of the solar brightness, once the solar radiation was directly related to the production rate of cosmogenic radionuclides (Masarik and Reedy, 1995).

Table 1 presents the results obtained in a cultivated area to verify the spatial variability of the beryllium-7. Spatial variability is an important parameter when radionuclides are used to determine the soil redistribution rates, because this variability is the predominant term in the propagated error of the soil redistribution values. The average inventory of beryllium-7 was 211 Bq. $\mathrm{m}^{-2}$ with a spatial variability around of $23 \%$. Andrello et al (2004b) presented spatial variability of cesium-137 in Londrina region as about $19 \%$. Although, cesium-137 and beryllium-7 has different origin, the spatial variability represents the topographic, microtopographic and pluviometric variability of the region.

Table 1 - Beryllium-7 concentration in the samples of cultivated area.

\begin{tabular}{cccc}
\hline Sampling Site & Depth Increments $(\mathbf{c m})$ & Activity $\mathbf{( B q \cdot \mathbf { k g } ^ { - \mathbf { 1 } } )}$ & Total Inventory $\left(\mathbf{B q} \cdot \mathbf{m}^{-\mathbf{2}}\right)$ \\
\hline P1 & $0-3 \mathrm{~cm}$ & $10.4 \pm 1.2$ & $327 \pm 13$ \\
P2 & $0-3 \mathrm{~cm}$ & $6.2 \pm 0.6$ & $195 \pm 6$ \\
P3 & $0-3 \mathrm{~cm}$ & $6.2 \pm 0.8$ & $195 \pm 9$ \\
P4 & $0-3 \mathrm{~cm}$ & $6.6 \pm 0.7$ & $209 \pm 8$ \\
P5 & $0-3 \mathrm{~cm}$ & $5.2 \pm 0.8$ & $159 \pm 8$ \\
P6 & $0-3 \mathrm{~cm}$ & $7.5 \pm 0.8$ & $237 \pm 9$ \\
P7 & $0-3 \mathrm{~cm}$ & $6.9 \pm 0.7$ & $218 \pm 7$ \\
P8 & $0-3 \mathrm{~cm}$ & $8.3 \pm 1.0$ & $261 \pm 11$ \\
P9 & $0-3 \mathrm{~cm}$ & $6.1 \pm 0.7$ & $191 \pm 7$ \\
\hline
\end{tabular}

\section{CONCLUSION}

It could be concluded that the beryllium-7 distribution in depth was similar as in literature. Beryllium-7 deposition flux was mainly due to humid precipitation and its presence only in $0-2 \mathrm{~cm}$ depth of soil confirmed the potential as a marker of superficial soil and use as source of soil erosion data.

\section{ACKNOWLEGMENTS}

Authors thank the CNPq for financial support on postdoctoral fellowship.

\section{RESUMO}

Berílio-7 é um radionuclídeo cosmogênico, com meia-vida de 53 dias, produzido pelo processo de espalação de átomos de oxigênio e nitrogênio dentro da troposfera e estratosfera. Após sua produção, este é transportado até a superfície terrestre pela deposição úmida e seca. A precipitação seca contribui somente com 3-8\% do inventário total. Medidas de berílio-7 no solo podem serem usadas para indicar movimento de solo da camada superficial e este estudo objetiva examinar o comportamento de berílio-7 no solo. Variabilidade natural do inventário de berílio-7 é em torno de $23 \%$ (desvio padrão relativo). A distribuição em profundidade de berílio-7 pode ser aproximada por uma função exponencial no solo nu, com uma profundidade média de distribuição no solo em torno de $1 \mathrm{~cm}$. O berílio-7 não foi encontrado abaixo da profundidade de $2 \mathrm{~cm}$ para o tipo de solo estudado, o que confirma sua utilização para avaliar processo de erosão superficial como um traçador de solo superficial. A concentração máxima de berílio-7 no período analisado é em torno de $40 \mathrm{~Bq} \cdot \mathrm{kg}^{-1}$.

\section{REFERENCES}

Andrello, A. C., Guimarães, M. F, Appoloni, C. R., Nascimento Filho, V. F., (2003). Use of Cesium-137 Methodology in the Evaluation of Superfficial Erosive Processes. Braz Arch Biol and Technol. 46, 307-314. 
Andrello, A. C., Guimarães, M. F, Appoloni, C. R., Nascimento Filho, V. F., (2004a). Soil Erosion Determination in a Watershed from Northern Paraná (Brazil) Using ${ }^{137}$ Cs. Braz Arch Biol and Technol. 47, 659-667.

Andrello, A. C and Appoloni, C. R., (2004b). Spatial Variability and Cesium-137 Inventories in Native Forest. Braz J Phys, 34, 800-803.

Blake, W.H., Walling, D.E., He, Q. (1999). Fallout beryllium-7 as a tracer in soil erosion investigations. Appl Radiat Isotopes 51, 599.

Daish, S. R., Dale, A. A., Dale, C. J., May, R., Rowe, J. E., (2005). The temporal variations of ${ }^{7} \mathrm{Be},{ }^{210} \mathrm{~Pb}$ and ${ }^{210} \mathrm{Po}$ in air in England. J. Environ. Radioact. 84, 457467.

Govers, G., Quine, T.A., Desmet, P.J.J., Walling, D.E. (1996). The relative contribution of soil tillage and overland flow erosion to soil redistribution on agricultural land. Earth Surf Proc Land 21, 929.

Loughran, R. J. (1989). The measurement of soil erosion. Prog Phys Geog 13, 216.

Matissoff, G., Bonniwell, E. C., Whiting, P. J., (2002). Soil erosion and sediment sources in an Ohio Watershed using Beryllium-7, Cesium-137 and Lead210. J. Environ. Qual., 31, 54-61.

Schuller, P., Iroumé, A., Walling, D. E., Mancilla, H. B., Castillo, A., Trumper, R. E., (2006). Use of Beryllium-7 to document soil redistribution following forest harvest operation. J. Environ. Qual., 35, 17561763.

Steinmann, P., Billen, T., Loizeau, J. L., Dominick, J., (1999). Beryllium-7 as a tracer to study mechanism and rates of metal scavenging from lake surface waters. Geochim et Cosmocheim Acta, 63, 16211633.
Toy, T. J., Foster, G. R., Renard, K. G., (2002). Soil Erosion: Processes, Prediction, Measurement, and Control. Wiley Press, New York, 352p.

Yoshimori, M., (2005). Beryllium-7 radionuclide as a traces of vertical air mass transport in the troposphere. Adv. Spac. Resear., 36, 828-832.

Walling, D.E., He, Q. and Blake, W. (1999). Use of ${ }^{7} \mathrm{Be}$ and ${ }^{137} \mathrm{Cs}$ measurements to document short- and medium-term rates of water-induced soil erosion on agricultural land. Water Resour Res 35, 3865.

Wan, G.J., Santschi, P.H., Sturm, M., Farrenkathen, K., Lucek, A.m Werth, E., Schuler, C. (1987). Natural $\left({ }^{210} \mathrm{~Pb},{ }^{7} \mathrm{Be}\right)$ and fallout $\left({ }^{137} \mathrm{Cs},{ }^{239+240} \mathrm{Pu},{ }^{90} \mathrm{Sr}\right)$ radionuclides as geochemical tracers of sedimentation in Greinfense, Switzerland. Chem Geol 63, 181.

Wallbrink, P.J., Murray, A.S. (1996). Distribution and variability of ${ }^{7} \mathrm{Be}$ in soils under different surface cover conditions and its potential for describing soil redistribution processes. Water Resour Res 32, 467.

www.iapar.br em agrometerologia, cartas climáticas.

Masarik, J. and Reedy, R.C. (1995). Terrestrial cosmogenic-nuclide production systematics calculated from numerical simulations. Earth Planet Sc Lett 136, 381.
Received: September 15, 2008; Revised: February 12, 2009; Accepted: November 13, 2009. 